First Peoples Child \& Family Review

An Interdisciplinary Journal Honouring the Voices, Perspectives, and Knowledges of First Peoples through Research, Critical Analyses, Stories, Standpoints and Media Reviews

\title{
Wanted: Moral Courage in Canadian Child Welfare
}

\section{Cindy Blackstock}

Volume 6, Number 2, 2011

URI: https://id.erudit.org/iderudit/1068875ar

DOI: https://doi.org/10.7202/1068875ar

See table of contents

\section{Publisher(s)}

First Nations Child and Family Caring Society of Canada

\section{ISSN}

1708-489X (print)

2293-6610 (digital)

Explore this journal

Cite this article

Blackstock, C. (2011). Wanted: Moral Courage in Canadian Child Welfare. First Peoples Child \& Family Review, 6(2), 35-46. https://doi.org/10.7202/1068875ar

\section{Article abstract}

Child welfare stifles change and innovation in a system that desperately needs it by promoting conformity and awarding subordination to bad ideas (Blackstock, 2009). If neglect means not doing the right thing for children even when you know better and can do better, and have the resources to do it, then too often child protection neglects First Nations children and their families. This essay explores whether emancipating moral courage in child protection is the key to ensuring good research translates into real benefits for First Nations families. This paper begins with a description of moral courage in child protection across the decades before drawing on my own experiences with moral courage in the child welfare field. It concludes with stories of how moral cowardice diminishes children and how moral courage uplifts them. Implications for research, policy and practice are discussed.
This document is protected by copyright law. Use of the services of Érudit (including reproduction) is subject to its terms and conditions, which can be viewed online.

https://apropos.erudit.org/en/users/policy-on-use/ 


\title{
First Peoples Child \& Family Review
}

An Interdisciplinary Journal Honoring the Voices, Perspectives and Knowledges of First Peoples through Research, Critical Analyses, Stories, Standpoints and Media Reviews

\section{Wanted: Moral Courage in Canadian Child Welfare}

\author{
Cindy Blackstock ${ }^{a}$
}

a Dr. Blackstock is the Executive Director of the First Nations Child and Family Caring Society of Canada, Ottawa, Ontario and is an Associate Professor at the University of Alberta.

\section{Introduction}

Child welfare stifles change and innovation in a system that desperately needs it by promoting conformity and awarding subordination to bad ideas (Blackstock, 2009). If neglect means not doing the right thing for children even when you know better and can do better, and have the resources to do it, then too often child protection neglects First Nations children and their families. For over a decade leading studies such as the Canadian Incidence Study on Reported Child Abuse and Neglect (CIS) have suggested that culturally based services targeted at poverty, poor housing and substance misuse would reduce the over-representation of First Nations children in child welfare care (Trocmé, Fallon, MacLaurin, Daciuk, Felstiner, Black, Tonmyr, Blackstock, Barter, Turcotte, 2006; Trocmé, MacLaurin, Fallon, Knoke, Pitman \& McCormack, 2006). Systemic changes to address these factors have been negligible (Blackstock, 2011). The problem for First Nations families is further aggravated by longstanding inequities in Federal

Questions or correspondence concerning this article may be addressed to:

Cindy Blackstock

Phone: 613.230.5885

cblackstock@fncaringsociety.com

www.fncaringsociety.com

\begin{abstract}
Child welfare stifles change and innovation in a system that desperately needs it by promoting conformity and awarding subordination to bad ideas (Blackstock, 2009). If neglect means not doing the right thing for children even when you know better and can do better, and have the resources to do it, then too often child protection neglects First Nations children and their families. This essay explores whether emancipating moral courage in child protection is the key to ensuring good research translates into real benefits for First Nations families. This paper begins with a description of moral courage in child protection across the decades before drawing on my own experiences with moral courage in the child welfare field. It concludes with stories of how moral cowardice diminishes children and how moral courage uplifts them. Implications for research, policy and practice are discussed.

Key words: First Nations children, youth, families; child welfare; child protection; moral courage; implications for research, policy and practice.
\end{abstract}

Government funding for child welfare services on reserves (McDonald \& Ladd, 2000; Auditor General of Canada, 2008; Standing Committee on Public Accounts, 2009; Auditor General of Canada, 2011). First Nations child and family service agencies broadly acknowledge the importance of these factors, but inequities in federal government funding regimes fetter the development of holistic services to deal with the problems (Auditor General of Canada, 2008; Blackstock, 2011). While the numbers of First Nations children in child welfare care continues to grow, provincial / territorial and federal governments point fingers at each other for a failure to provide relevant, culturally based and equitable services while the children and their families suffer (Auditor General of Canada, 2008; Blackstock, 2011). It has gone on for decades and it needs to stop - but how? 
Some suggest that improved knowledge translation strategies are required. While I agree that making research accessible and relevant to child protection policy makers and practitioners is important, it is not enough. In the case of the CIS, the findings are very accessible, broadly known and yet child welfare has done little to re-tool the system to address the factors undermining child safety and wellbeing. For example, very few child protection workers get any serious training on poverty reduction or substance misuse assessment and response even though the CIS has repeatedly found that these are key factors related to the over-representation of First Nations children. This paper explores whether emancipating moral courage in child welfare is the key to ensuring good research and ethical standards translates into real benefits for First Nations families. It begins with a description of moral courage in child protection across the decades before drawing on my own experiences with moral courage in the child welfare field. The paper concludes with stories of how moral cowardice diminishes children and how moral courage uplifts them. Implications for research, policy and practice are discussed.

\section{What is Moral Courage?}

Moral courage is the ability to stand up for the "right thing", or do the "right thing" when some negative repercussion for the right-doer is anticipated (Kidder, 2003). Moral courage happens in all aspects of social work life. It is needed to blow the whistle on longstanding rights violations perpetrated by powerful institutions and individuals. It is needed when pressing for better services for clients requires rocking the boat with colleagues or the employer. It involves what I call "getting into trouble for doing the right thing" and what Bird and Waters (1989) call "courageous conversations." Courageous conversations involve the public expression of personal or professional principles and/or values in situations where such expression is likely to be challenged. This is often a difficult step. People are often willing to mull over courage in the privacy of their own thoughts or in confidential conversations but giving public voice to morally courageous stances often makes them more real, irrevocable and risky (Bird \& Waters, 1989). The degree of moral courage required increases as the risks for the right-doer become more personal and intense (Bauman 1989; Kidder, 2003). Kidder (2003) argues that people are more apt to be morally courageous when personal benefit is on offer than to stand up for the rights of strangers. Leading philosophers such as Joseph Needleman (2007) argue that people are by nature self-interested and only become altruistic through life-long practice of moral coherence and courage.

Determining right versus wrong is a question preoccupying leading philosophers through the ages (Campbell \& Moyers, 1991; Needleman, 2007). It invokes questions of values, of whose good is being promoted and at what expense to others. For the purposes of this paper, "the moral right" is based on multiple sources of good evidence, activation of social work values, communal interests, and a weighing of the implications beyond the beneficiaries. On a practical level, it is measured by whether social work does the right thing for people beyond close circles of self-interest and relationships when it knows better and can do better. It is one thing to stand up for yourself or for those you love, but it takes an uncommon level of courage to stand up for people you do not know and that is exactly the type of moral courage that child welfare needs in abundance. A caution is necessary here before I begin enthusiastically suggesting that child welfare workers and others begin challenging the system. A warning label if you like. Standing up can be misguided if based on self-interest, ambition, unresolved personal issues, and weak research. These same perils are associated with not speaking up and taking action when it is clearly necessary but for some reason it rarely invokes the same moral deliberation that taking action does (Needleman, 2007). In many settings it seems that doing nothing or doing just a little to relieve the social worker's moral burden, without truly addressing the situation is an accepted practice reinforced by bureaucratic systems that reward conformity (Milloy, 2005; Blackstock, 2009). I believe that we should not give a moral hall pass to the social work by-stander who allows injustice to exist or 
embolden in silence (Bauman, 1989; Campbell \& Moyers, 1991; Needleman, 2007; Blackstock, 2009; Blackstock, 2011).

Moral courage invokes important discussions about what values guide morally courageous stances and how social workers can ensure they are not morally acting in value oppressing ways. There is no doubt that the expression of values is culturally laden, however, Kidder (2003) argues that five universal human values provide a common foundation for expressions of moral courage. The universal values are: honesty, respect, responsibility, fairness and compassion. Courage is not a value on its own but rather an activating agent for the universal values (Kidder, 2003). I believe this model is highly consistent with First Nations traditional values and worldviews. The universal values are also embedded in Canadian social work codes of ethics (Canadian Association of Social Workers, 2005) meaning that morally courageous social work can be morally coherent with the universal values whilst respecting diverse cultural manifestations.

Child welfare requires an uncommon level of moral courage. To begin with, child welfare bureaucracies are, by nature, structured for conformity not innovation. Standing up against the child welfare bureaucracy, even for the right thing, can mean risking your job (Bauman, 1989; Milloy, 2005; Blackstock, 2009). Second, the risks arising from conformity are usually borne by clients rather than workers or child welfare bureaucrats suggesting that there is little personal harm for employees and managers associated with not rocking the boat (Milloy, 2005). Thirdly, in the case of First Nations child welfare on reserve, multiple government bureaucracies may need to be challenged with multiple consequences such as agency funding cuts, increased regulation or blacklisting (Blackstock, 2011). Fourth, child death reviews and critical incidence continue to drive policy and practice despite impressive evidence that these cases are atypical and nonrepresentative of the vast majority of families served by child welfare (Trocmé, MacLaurin, Fallon, Daciuk, Billingsley, Tourigny, Mayer, Wright, Barter, Burford, Hornick, Sullivan, \& McKenzie, 2001; Trocmé, MacLaurin, Fallon,
Knoke, Pitman, \& McCormack, 2006). The tragic nature of child deaths and the lack of knowledge among child death review report authors about the atypical nature of these cases often results in a misapplication of recommendations across the entire system. Moreover, the high public profile of child death reviews creates fertile ground for fear based decision-making, and thus moral inertia throughout the child welfare system (Blackstock, in press).

Despite these barriers, I have routinely seen courageous line workers and supervisors bend the rules to do the right thing for children and then hope no one in management finds out. Policy making in child welfare is largely a top down affair. I was a line child protection worker for over a decade in a provincial child welfare system and I cannot recall a single time when policy wonks or management asked me, or any of my colleagues, what policies we thought should be changed or developed. Today, my informal straw polls of child protection workers in Canada and abroad suggest that little has changed. Research on the incidence of child protection policy rule breaking and the factors contributing to it should be investigated $-\underline{\text { not }}$ as an enforcement measure but rather to make alive the innovations workers are doing to improve the lives of children and families despite the system.

To be fair to the child protection bureaucracy, I was "consulted" on two Ministry child protection policies when I was a child protection worker but these were already pretty much decided on. One of my earliest experiences with child welfare policy consultation came shortly after I was hired. A person in a business suit that I never saw around the office before came in and said that after careful review the Ministry had decided that future hires needed to have a Bachelor of Social Work degree. Being naive enough to believe that child welfare policy must be based on evidence - I asked what evidence supported the idea that people with Bachelor in Social Work degrees were more effective child protection workers than those of us who had other types of degrees. The man in the suit became defensive. He suggested I would understand when I got older and became more experienced. He never answered my question and the requirement 
was imposed anyway. We never saw him again. Twenty-five years and two graduate degrees later I am still waiting for definitive evidence that people with Bachelor of Social Work degrees make better child protection workers.

The next consultation happened years later. The Ministry was over-hauling the child welfare act. A group of policy managers arrived and gave a spiel on the proposed changes to approximately 100 child protection workers in the room and provided less than 30 minutes for us to "provide feedback." Then they showed us the completed copy of the report - already in print. Not surprisingly, my colleagues and I had little confidence that the few ideas we were able to share would be seriously considered. My conversations with child protection workers coupled with my observations of child welfare policy development today suggests that child protection workers are rarely looked to as a primary idea source for policy change.

This top down structure in child welfare suggests that one of the important moral courageous steps is for policy-making to include line workers, children and families and other stakeholders.

There is no meaningful discussion on moral courage at different levels of child welfare practice but there are important historical examples that serve as important examples of the importance of moral courage and should inspire research on the role of moral courage in social work today.

\section{Moral Courage: Is it important for the child welfare system to do better?}

In 1907, a doctor said what child protection social workers did not. First Nations children in residential schools were dying from maltreatment and preventable causes of disease. Dr. Peter Henderson Bryce went public with the shocking revelation that over a third of children placed in government funded and church operated residential schools were dying there. Bryce said, "medical science knows just what to do" to prevent the children from dying and yet Canada failed to implement the reforms necessary to save countless lives (Bryce, 1922; Milloy, 1999). Bryce stepped up his advocacy reaching out to leading human rights lawyers such as S.H. Blake who famously said: "in that Canada fails to obviate the preventable causes of death, it brings itself into unpleasant nearness to manslaughter" (Milloy, 1999 p. 77). Bryce spent his entire life advocating with the Canadian Government to stop the needless deaths of First Nations children but Canada continued its wayward policies and children died. Bryce, however, did not fail. He succeeded in acting with moral and professional coherence supported by good evidence. He never gave up despite Canada's efforts to dismiss or discredit him or his concerns. $\mathrm{He}$ is a true Canadian hero who acted with moral coherence and yet the Canadian public and many social workers know little of him and thus do not have a chance to learn from his example.

Wekeep repeating the same mistakes. Sixtyyears after Bryce raised the alarm about government policies toward First Nations children not being evidence based or morally just, social workers were responsible for placing as many as 80 percent of all children in residential schools as child welfare placements (Caldwell, 1967). There was no meaningful activism from child protection to address the ongoing abuse and mistreatment (Caldwell, 1967; Milloy, 1999). Eighty years later, Justice Edwin Kimmelman (1985) said that the en mass removals of Aboriginal children by the child welfare system and their placement in non-Aboriginal homes in the 1960's and 1970's amounted to cultural genocide. Although social workers in Canada widely admonish this poor practice, the real question is what have we learned and do we have the moral fortitude to put those lessons learned into practice?

One hundred and four years after Bryce first raised the alarm, there are more First Nations children in child welfare today than at any time in history with placement rates 6-8 times higher than for non-Aboriginal children (Auditor General of Canada, 2008). Data collected in 1998 by the Canadian Incidence Study on Reported Child Abuse and Neglect [CIS] (Trocmé, MacLaurin, Fallon, Daciuk, Billingsley, Tourigny, Mayer, Wright, Barter, Burford, Hornick, Sullivan, \& McKenzie, 2001) found that poverty, poor 
housing and substance misuse substantially accounted for the over-representation of First Nations children in child welfare. Results were later replicated in the 2003 cycle of the CIS (Trocmé, MacLaurin, Fallon, Knoke, Pitman, \& McCormack, 2006). In 2000, the Canadian Government and the Assembly of First Nations commissioned a national study. This study confirmed the 1998 CIS findings and found that Canada was providing about 22 percent less funding for First Nations child welfare on reserves than the provinces provided to all other Canadians (McDonald \& Ladd, 2000). This under funding threatened the basic operation of First Nations child welfare agencies and fettered their ability to address the factors driving the over-representation in culturally based ways (McDonald \& Ladd, 2000). The need to redress the Federal Government funding inequities in on reserve child welfare were later confirmed in a detailed expert report commissioned by the Department of Indian and Northern Affairs and the Assembly of First Nations in 2005 (Loxley, De Riviere, Prakash, Blackstock, Wien, \& Thomas Prokop, 2005) and then again by the Auditor General of Canada $(2008,2011)$.

Despite this evidence, child welfare authorities across Canada bemoan the growing overrepresentation of First Nations children in care whilst continuing to view child welfare funding inequities, poverty, poor housing and substance misuse as tangential concerns versus the central work of child welfare. Even the most modest reforms such as providing increased training to social workers on poverty and substance misuse have largely been ignored (Blackstock, 2011).

Research is necessary to inform good public policy especially with regard to children but can also be used as an excuse to put off acting on what we know. Policy makers too often say more research is needed even when there is good evidence to take significant steps. These policy makers often use phrase such as the "situations is complex" to justify inaction even in when immediate action is needed to remediate rights violations for First Nations children. Studies pile up and nothing really changes for kids. Thinking back to Kidder's (2003) universal values, research is a truth-telling mission and thus a good proxy for the value of honesty but honesty on its own has no effect unless activated by moral courage. Just as in Bryce's time, child protection often knows "what to do" but does not have the moral courage to do it.

I am proud of the First Nations child welfare agencies doing grass roots driven work that uplifts families and children despite the constraints imposed by federal and provincial governments. I am also encouraged to see some provincial governments working with First Nations to innovate and create morally courageous approaches to child welfare such as the Touchstones of Hope program in Northern British Columbia (First Nations Child and Family Caring Society of Canada, 2011). Morally courageous policy environments in child protection bureaucracies and schools of social work would help these positive examples become the rule instead of the exception.

Moral courage requires an individual to understand their moral values and, through practice and reflection. A review of the literature revealed no studies on moral courage in child protection so I share my own personal experience to show how moral courage has become foundational to my social work practice.

\section{Moral Courage in Child Protection: On a Personal Note}

My own experience suggests that moral courage in child welfare can be a messy and dangerous undertaking. I have won many national and international awards but the one that I am now most proud of, and had the greatest influence on me, is the letter of insubordination I received when I was a young child protection worker.

I was just 21 when I was hired as a child protection worker. Too young to be doing a job where life experience was more valuable than what I learned in university and too young to know it. I still have the posting for this child protection job. It says "[S]ocial Work, You can make a difference" and reading it now I can see conformity woven into the text. Phrases like "interpreting Ministry policy" or "within Ministry policy" suggest that the employer has already deemed policy as benevolent and 
good - undeserving of questioning by those who implement it (Ministry of Social Services and Housing, 1986). Yet, the 21-year-old version of me read the posting and thought the government wanted young hard working leaders. That is what I wanted the posting to say, but in truth the words "young "and "leadership" appeared nowhere in the text.

I went to child protection training where the safety and well being of children were identified as primary considerations in child welfare practice. I believed it. I was too young and inexperienced to understand that safety and well being of the institution, and in some cases the political figures that headed it, sometimes usurped the safety and well-being of the children. What continues to amaze me is how easy it is for people to clearly act in self-interest or institutional interests and reframe that as not betraying the interests of the child and family. People would blame "the system" say we need to do "what is possible" which was often code for what was "politically possible", make trade-offs, encourage "patience" when it is not warranted, or simply ignore the facts. The ability of good people to rationalize immoral behavior is just as Bauman (1989) suggests - possible even in the most egregious moral situations. It is scary when immoral behavior becomes possible for everyone and especially scary for those working in helping fields. It lies in contradiction to social work professional identifications as the good guys (Blackstock, 2009). There should be high degrees of systemic moral vigilance in helping professions but in my experience there rarely is. Social workers lose sleep over a family but the system itself usually rests pretty easily. Child welfare organizations seem more comfortable proclaiming morality and acting as if everything they do is fundamentally benevolent than to be alive to the possibility that their best intentions can "pave the way to hell."

The pressure to conform was driven from the top, strengthened by middle management and was most acutely felt by those of us at the bottom of the bureaucracy and pay scale who had the most direct contact with clients. The pressure to conform intensified when management lacked confidence and/or came under pressure from media or political forces particularly when a child died or there was a critical incident reported in the press. Fear was a key tool in the bureaucratic arsenal to keep questioning employees in line. I still remember middle managers saying that if we stepped out of line there would be at least ten other people happy to get our jobs. I was afraid for a while. I wanted to do well for myself and for my family but then I realized something. No one ever got fired, prospective employees were not lined up outside our door and I had no ambition to rise through the ranks. I, therefore, decided to do my work based on values, consultation with respected colleagues and community members and as much common sense as I could muster.

For years, I was largely ignored at the bottom of the bureaucracy until one day I did something that got me noticed. I refused a direct order by middle management to investigate a child protection complaint filed by a politically powerful member of the community on a young family. I knew all too well how difficult child protection investigations are for families and in my view, and that of my supervisor and colleagues, there was no reason to investigate. The decision to investigate is not a decision to be taken lightly or for political reasons. Middle management quickly issued letters of reprimand for insubordination to my supervisor and I. We posted these letters on the staff bulletin board instead of keeping it secret. The posting on the bulletin board made management even more uncomfortable because we were prepared to be publically accountable for our decision. On second thought, maybe management was even more worried that insubordination could be contagious. Long story short - the letter of reprimand for insubordination was over-turned after the union intervened and as far as I know the family was never subjected to the unnecessary child protection investigation.

As I write this incident, I sound much more courageous and determined than I actually felt at the time. When I decided to say "no" to management I knew the consequences could include being fired or hitting the glass ceiling. I was worried about the former as I had rent to pay but not the latter as I had already figured out that I was not cut out for the conformity demanded in bureaucratic child welfare organizations. I was 
too much of a troublemaker to rise through the ranks. Even though I was willing to take the risk of saying "no" for what I believed to be good reasons, it did not make enduring the risk an enjoyable experience nor was I always as eloquent as I would have liked to have been in making my protest. Still, I am glad I took this stand on values. It was the one of the most emancipating experiences of my life. Bureaucracies rely on holding something you value in order to get people to conform (Bauman, 1989). In my case, they used words like "loyalty," while suggesting that superiors knew best and when that failed to get me to conform they resorted to the tried and true threat of "we pay your paycheck." When I allowed my values to usurp these concerns, I set myself free.

Thankfully, I had historical and contemporary role models like P.H. Bryce, my mom, Hennie Kerstiens, Joan Glode of Mik'maw Family and Children's Services and children like Shannen Koostachin and Jordan River Anderson who mentored me on moral courage. Their examples gave me the fortitude to tackle the worry that I may not have the strength to try to live a morally courageous life. The struggle to live in morally courageous ways can be depleting and I sometimes worried that the energy needed to "do right" had an expiration date. I sometimes tire of that tightness in my stomach, the unproductive rambling thoughts before sleep and that tug between "smoothing things over" and doing the right thing. Others would tell me that "smoothing things over" or compromising so the wrongdoer "saves face" was the right thing to do - I always found that impossible when it meant a compromise of fundamental values. My mentors 'guidance was particularly useful at these times. They would always say do what you know in your heart is the right thing to do.

These moral tests, big and small, were moral courage practice sessions that eventually set the stage for filing a human rights complaint, in 2007, against Canada alleging racial discrimination against First Nations children by under-funding child welfare on reserves (Blackstock, 2011). There is significant evidence of the funding inequity and its connection with the rising numbers of First Nations children in child welfare care (Auditor General of Canada, 2008; Standing Committee on Public Accounts, 2009, Blackstock, 2011). Within weeks of filing the human rights case, the Canadian government began its efforts to derail the case using legal technicalities in an apparent effort to avoid a hearing on the merits. There were also personal and professional implications to filing this case. As one of the complainants, my organization no longer gets any funding from the federal government. There is no direct evidence to suggest the filing of the case is linked to the funding cuts but it is worth remarking that we are, to my knowledge, the only national Aboriginal organization to receive no money from the federal government. Canada has assigned the same lawyers who fought against residential school survivors to fight this landmark case testing whether Canada can be held accountable for discrimination arising from its policies and funding regimes (Blackstock, 2011). When I testified under oath during one of Canada's many attempts to dismiss the case on legal technicalities, Canada's lawyer asked me if I believed in God and whether I was in child welfare care as a child (Blackstock, 2011). Canada told First Nations leaders that government officials would not meet with them if I attended the meeting. Access to information documents suggest that the Government of Canada monitors postings on my personal Facebook page, has inexplicably pulled information on my family and has spent thousands of dollars sending government employees to report on my presentations and meetings (INAC, 2010; Aboriginal Peoples Television Network, 2011; CBC, 2011). The Government of Canada is undertaking an internal investigation of the matter. While I am pleased to see the investigation, I would prefer a more independent review process particularly as the person charged with the investigation is copied on the documents in question. Although these activities are deeply unsettling, they are not enough to dissuade me from speaking out for the children. I will not give up.

The pressure to conform and let the Canadian Government continue its inequitable policies for First Nations children is immense but instead of feeling weighted, I feel free. It is easier I have learned to live with moral courage than it 
is to live with fear. I am also emboldened by the outpouring of public support. I believe that publicity is an effective inoculation to poor government policy and behavior. The idea of inviting the public to watch Canada's policy and behavior is what inspired the "I am a witness" campaign for the human rights case on child welfare. The "I am a witness" campaign invites Canadians to follow the legal case on a resource rich website that posts all legal documents, including testimony, for everyone to read. Instead of requiring witnesses to take one side of the case or another, people are invited to use their own good judgment to decide if Canada is treating First Nations fairly. Over 8600 Canadians and organizations have responded making the First Nations child welfare tribunal the most formally watched legal proceeding in Canadian history (Blackstock, 2011). Oppression, I have learned, does not like a witness.

In my mind, there is a direct developmental line between my letter of insubordination and the ability to withstand the significant pressures that the Canadian Government is employing to quash the human rights complaint. The letter of reprimand was a practice session for the main challenge currently before me. Despite what I view as unbecoming conduct by the Canadian government and some government officials, I am not afraid. I know their power - it is just their power does not reach to the core of what I truly value. I consciously try to live by values and judge the quality of my life by my ability to do so. I have come to understand that the easy wrong is not the stuff of a satisfying life. The easy wrong stifles personhood, it strips us of who we are, it cages. Living by values liberates. Whatever comes next, I now feel ready - not arrogant and not unafraid - just ready to accept the challenge.

A critical reader is now asking whether or not my experience is typical of those in child welfare. It is a legitimate question requiring further research. Such research would help us better understand if moral courage is a useful lens for understanding why adults sometimes fail to protect children even when they have the knowledge and resources to do so.

\section{Moral Cowardice Diminishes; Moral Courage Uplifts}

A sexual abuse cover-up scandal has just broken at Pennsylvania State University (Penn. State). A popular assistant football coach has been indicted for sexually abusing young boys in university football facilities for over a decade (Daily, 2011). Although evidence is still emerging, it seems clear that many adults in the organization knew the sexual abuse was happening and failed to take meaningful measures to intervene. The University Board of Directors has now fired many of the senior administrators for failing to protect the children. While most people are concerned with the wellbeing of the young boys who were victimized, a sizeable number are trying to protect the rights of those who through inaction or inadequate action allowed the abuse to continue. Arguably, the most morally courageous in this case were the children who had the strength to report their abuse by a very powerful community member. It is the adults in this case, both those who did not protect the children when they knew of the abuse and those who rose to defend them, who embody moral cowardice (Daily, 2011). There is an important question as to whether the moral cowardice of adults and systems involved in this case are unique or are they characteristic of what many other adults would do in similar situations? Further research is needed to properly answer this question. However, other cases of child abuse cover-ups in residential schools, churches and military operations seem to indicate that it is possible that adults are more likely to act with moral cowardice than with courage when it comes to protecting children.

Moral cowardice and courage happens in many settings where the interests of children and adults interface. The Pennsylvania State University example shows how moral cowardice can occur in settings where physical courage is lauded. Moral cowardice can also infuse organizations that prioritize child rights and laud morality and justice such as social work organizations and child welfare. For example, we need to critically reflect on whether moral courage/ cowardice helps us better understand why child 
welfare systems are not meaningfully changing their policy and practice when good evidence suggests addressing poverty, poor housing and substance misuse could substantially improve outcomes for children. Moral cowardice may also be at the root of the Federal Government's ongoing discriminatory policies and funding regimes affecting First Nations children and their families.

First Nations Elders acting on the basis of traditional values teach by role modeling (Blackstock, 2008). They act in ways that link values with behavior creating integrity. Dr. Laura Markham (2011) suggests that parents have a direct impact on the development of moral courage of their children not by what they say but rather by acting in morally courageous ways themselves. Markham (2011) says that parents can role model moral courage in every day events such as letting the cash register clerk know that they gave you too much change and acknowledging their own mistakes and taking action to correct them. I think this should be true of child welfare too. If social workers want parents to act in morally courageous ways then we need to be good role models.

There are also examples where the moral courage of children is instructive. For example, five year old Jordan River Anderson died after having spent two and a half years unnecessarily in hospital because provincial and federal governments could not agree on who should pay for the at-home services for this First Nations boy. If he were non-Aboriginal, he would have gone home when doctors were ready to discharge him just after his second birthday. Instead of suing the governments, his parents simply asked that this not happen to another child. Jordan's Principle is a child first principle to resolving jurisdictional disputes that fetter First Nations children from getting the same quality and quantity of government services as all other children (MacDonald \& Attaran, 2007). In December of 2007, the Canadian House of Commons unanimously passed a private members motion in support of Jordan's Principle, yet four years later the Federal Governments has failed to develop systemic procedures to identify and respond to, Jordan's Principle cases. No province or territory has fully implemented it either, meaning many First Nations children are denied government services, or provided the service at a lesser quantity or quality, than is available to all other children. Advocates continue to press government to fully honor Jordan's Principle and properly implement it to ensure non-discrimination in public service access for First Nation children (Blackstock, 2011). With over 5300 supporters including the Assembly of First Nations, Canadian Medical Association, Canadian Teachers Federation, Canadian Federation of Nurses Unions and UNICEF, Jordan's Principle is now one of the most broadly supported children's policies in Canadian history (Blackstock, 2011).

Thirteen year old Shannen Koostachin of Attawapiskat First Nation spoke truth to power when she told the Canadian Government that she did not believe them when they said they had no money to build a new school to replace the broken down portables sitting next to a toxic waste dump that passed for a "school" in her community. She could not rationalize the fact that all First Nations children get less funding for education because of their race. She did not make it comfortable or polite for others to rationalize it either (Office of the Child and Youth Advocate and the First Nations Child and Family Caring Society of Canada, 2011). She was scared but she was determined to live in the way her parents raised her - pledging allegiance to the 7 grandfather teachings and the Creator. She did not give up when the Minister of Indian Affairs told her she would not get a new school. Shannen said that the activism she and the other children had undertaken is "just the beginning." Using You Tube and Facebook, Shannen asked children across Canada to join what was then called the "Attawapiskat School Campaign." Letters from thousands of children, young people and supporting adults arrived in Canada's mailbox demanding safe and comfy schools and equitable education. Shannen sadly passed away at the age of 15 before seeing her dream of proper schools and equitable education for all First Nations children realized. Her spirit has inspired thousands of Aboriginal and non-Aboriginal children to get the 
Canadian Government to do the hard right (own up to the discrimination and put an end to it) versus the easy wrong (looking the other way or minimizing the problem). The Shannen's Dream campaign, named in her memory, embodies her moral strength and is supported by thousands of children and adult allies. This campaign involves children writing letters to the Prime Minister and other political officials demanding culturally based equity in First Nations education. First Nations and other children have written hundreds of letters, raised awareness about Shannen's Dream in their schools and communities and marched onto Parliament Hill with Shannen's Dream signs in hand. In 2011, First Nations children fulfilled a promise that Shannen made to the Canadian Government by writing a report to the United Nations called Our Dreams Matter Too (Office of the Child and Youth Advocate and the First Nations Child and Family Caring Society of Canada, 2011). The children who wrote this report ask the United Nations to send a representative to speak with children across Canada about the importance of ensuring all First Nations children have equitable and culturally based education and other services (Office of the Child and Youth Advocate and the First Nations Child and Family Caring Society of Canada, 2011). Shannen's Dream is currently supported by over 6000 caring Canadians and the movement continues to grow.

Jordan, Shannen, their families, communities and the thousands of children they have inspired show how moral courage liberates and uplifts while moral cowardice diminishes.

\section{Conclusion}

Looking back on my personal experiences and the literature, a multi-level research and critical reflection approach is needed to explore the role of moral courage in social work and more specifically in child welfare work. Research is needed to identify moral courage incidence rates in social work and the personal and organization factors contributing to it. Impacts of moral courage for the right doers, clients and child welfare organizations and systems also require further research. Rule breaking in child protection needs to be critically analyzed to determine whether it is the breaking of the rule or the rule itself that is unjust. Differentiating between just and unjust policy and rules must be informed by good evidence, the universal values advanced by Kidder (2003), policy results and meaningful consultation with those involved in, and affected by, social work interventions.

As social workers we need to explore our own values and the alignment of those values with the universal moral values that Kidder (2003) identifies. Schools of social work and social work professional organizations need to reflect on courage as an activation tool for social work codes of ethics. Efforts must be made to reward morally courageous social work in research, policy and practice. Moral courage is not an endowment rather it is something requiring lifelong dialogue, learning and practice.

The consequences of failing to center moral courage in social work discussions and practice as well as among community members involved with the safety and wellbeing of children need to be explored. The systemic nature of our failure to do better when we know better and can do better demands nothing less.

\section{References}

Aboriginal Peoples Television Network (2011). Federal Aboriginal Affairs Department spying on advocate for First Nations children. Retrieved November 19, 2011 at http://aptn.ca/pages/news/2011/11/14/federalaboriginal-affairs-department-spying-on-advocate-forfirst-nations-children/

Auditor General of Canada (2008). First Nations Child and Family Services Program-Indian and Northern Affairs Canada. 2008 May: Report of the Auditor General of Canada. Retrieved May 31, 2008 from http://www.oag-bvg.gc.ca/internet/English/aud_ch_ oag_200805_04_e_30700.html\#hd3a

Auditor General of Canada (2011). Programs for First Nations on Reserves: 2011 June status report of the Auditor General of Canada. Retrieved July 12, 1011 from http://www.oag-bvg.gc.ca/internet/English/parl_ oag_201106_e_35354.html.

Bauman, Z (1989) Modernity and the holocaust New York: Cornell University Press. 
Bird, F. \& Waters, J (1989) The moral muteness of managers. California Management Review, 32.1: 173-88.

Blackstock, C. (in press). Child welfare: lessons from The Emperor's new clothes. In D. Fuchs, I. Brown and S. MacKay (Eds), Awakening the Spirit.

Blackstock, C. (2003). First Nations child and family services: Restoring peace and harmony in First Nations communities. In K. Kufeldt \& B. McKenzie (Eds.), Child Welfare: Connecting Research Policy and Practice (pp. 331-342). Waterloo, ON: Wilfred Laurier University Press.

Blackstock, C. (2008). Reconciliation means not saying sorry twice: Lessons from child welfare in Canada. From truth to reconciliation: Transforming the legacy of residential schools. Ottawa: Aboriginal Healing Foundation.

Blackstock, C. (2009). The occasional evil of angels: learning from the experiences of Aboriginal peoples and social work. First Peoples Child and Family Review, 4(1), 28-37.

Blackstock,C. (2011). The Canadian Human Rights Tribunal on First Nations Child Welfare: Why if Canada wins, equality and justice lose. Children and Youth Services Review, 33, 187-194.

Bryce, P.H. (1922). The story of a national crime: an appeal for justice to the Indians of Canada. Ottawa: James, Hope \& Sons.

Caldwell, G. (1967). Indian residential schools: A research study of the child care programs of nine residential schools in Saskatchewan. Ottawa: The Canadian Welfare Council.

Campbell, J. \& Moyers, B. (1991). The Power of Myth. New York: Random House.

Canadian Association of Social Workers. (2005). Code of Ethics. Retrieved November 19, 2011 at http://www. casw-acts.ca/sites/default/files/attachements/CASW_ Code\%20of\%20Ethics_e.pdf.

CBC. (2011). The Current: Govt surveillance of native youth advocate Cindy Blackstock. Retrieved November 19, 2011 at http://www.cbc.ca/thecurrent/ episode/2011/11/17/govt-surveillance-of-native-youthadvocate-cindy-blackstock/

Daily, K. (2011). Penn State: would you do better than Joe Paterno? British Broadcasting Company. Retrieved November 12, 2011 at http://www.bbc.co.uk/news/ magazine-15668834
First Nations Child and Family Caring Society of Canada. (2011). Touchstones of hope in northern BC. Retrieved June 18, 2011 at http://northernbctouchstones.ca/ northernbc.php

Indian Affairs and Northern Development [INAC] (2010). Access to information email sent by Natalia Strelkova to AFN Team [later clarified by Natalia Strelkova to be an internal government group not affiliated with the Assembly of First Nations], Krista Robinson and Nataliak Strelkova dated May 14, 2010 and sent at 9:56 AM. Access to information document number 000371.

Kidder, R. (2003). Moral courage: taking action when your values are put to the test. New York: Harper Collins.

Kimmelman, E. (1985). No quiet place: Manitoba review on Indian and Métis adoptions and placements. Winnipeg: Manitoba Ministry of Community Services.

Loxley, J., De Riviere, L., Prakash, T., Blackstock, C., Wien, F., \& Thomas Prokop, S. (2005). Wen: de: the journey continues. Ottawa: First Nations Child and Family Caring Society of Canada.

MacDonald, N \& Attaran, A. (2007). Jordan's principle: government's paralysis. Canadian Medical Association Journal, 177 (4), doi:10.1503/cmaj.070950.

MacDonald, R. and Ladd, P. (2000). First Nations child and family services joint national policy review: final report, June 2000. Ottawa, ON: Assembly of First Nations.

Markham, L. (2011). Courage. Parenting tips - raise great kids- Ahaparenting.com. Retrieved July 12, 2011 from http://www.ahaparenting.com/parenting-tools/ raise-great-kids/child-character/courage

Milloy, J. (1999). A National Crime: the Canadian government and the residential school system 18791986. Winnipeg: University of Manitoba Press.

Milloy, J .(2005). How do bad things happen when good people have good intentions? Retrieved October 6, 2011 at http://www.reconciliationmovement.org/docs/ Milloy_Oct2005.pdf

Ministry for Social Services and Housing. (1986). Social Work: You can make a difference. Victoria: Government of British Columbia.

Needleman, J. (2007). Why can't we be good? New York: Putnam.

Office of the Child and Youth Advocate and the First Nations Child and Family Caring Society of Canada. (2011). Our Dreams Matter Too. Toronto: Office of the Child and Youth Advocate. 


\section{Wanted: Moral Courage in Canadian Child Welfare}

Royal Commission on Aboriginal Peoples. (1996). Report of the Royal Commission on Aboriginal Peoples. Ottawa, ON: Indian and Northern Affairs Canada.

Trocmé, N., MacLaurin, B., Fallon, B. Daciuk, J. Billingsley, D., Tourigny, M., Mayer, M., Wright, J., Barter, K., Burford, G., Hornick, J., Sullivan, R., \& McKenzie, B. (2001). Canadian incidence study of reported child abuse and neglect: final report. Ottawa, ON: Health Canada.

Trocmé, N., Fallon, B., MacLaurin, B., Daciuk, J., Felstiner, C., Black, T., Tonmyr, L., Blackstock, C., Barter, K., Turcotte, D. (2006). Canadian incidence study of reported child abuse and neglect - major findings (2003). Ottawa: Public Health Agency of Canada.

Trocmé, N., MacLaurin, B., Fallon, B., Knoke, D., Pitman,L., \& McCormack, M. (2006). Mesnnmimk Wasatek: catching a drop of light: Understanding the overrepresentation of First Nations children in Canada's child welfare system: An analysis of the Canadian Incidence Study of Reported Child Abuse and Neglect (CIS-2003). Ottawa: First Nations Child and Family Caring Society of Canada. 